\title{
Erratum: HIV immunity goes direct
}

Editorial

Nat. Biotechnol. 32, 397 (2014); doi:10.1038/nbt.2907; published online 8 May 2014; corrected after print 5 June 2014

In the version of this article initially published, AAV1 was incorrectly identified as AAV9. It was not noted that the Surrey Clinical Research Centre is at the University of Surrey. The phase 1 clinical trial is for a gene transfer, not a gene therapy, and will test whether levels of AAV1 encoding, not expressing, PG9 will neutralize HIV in cell culture. Finally in the third from last paragraph, the question posed is "will vector-mediated gene transfer drive expresssion" not "will AAV9 drive expression." These errors have been corrected in the HTML and PDF versions of the article.

\section{Erratum: University biotech patenting 2013}

\section{Brady Huggett \& Kathryn Paisner}

Nat. Biotechnol. 32, 512 (2014); published online 9 June 2014; corrected after print 10 July 2014.

In the version of this article initially published, the total number of patents assigned to Cornell in Table 1 was incorrect. The correct number for the 2009-2013 time period is 122. Also, total patents assigned to Penn State and Purdue were 45 apiece over the time period, bringing them in above Ohio State University and INSERM, which they replace in our ranking in Table 1 . The errors have been corrected in the HTML and PDF versions of the article.

\section{Erratum: In Their Words}

Nat. Biotechnol. 32, 507 (2014); published online 9 June 2014; corrected after print 18 June 2014

In the version of this article initially published, a headshot of Floyd Romesberg incorrectly appeared next to a quote from Tony Wyss-Coray. The error has been corrected in the PDF version of the article.

\section{Corrigendum: Genome editing with Cas9 in adult mice corrects a disease mutation and phenotype}

\section{Hao Yin, Wen Xue, Sidi Chen, Roman L Bogorad, Eric Benedetti, Markus Grompe, Victor Koteliansky, Phillip A Sharp, Tyler Jacks \& Daniel G Anderson Nat. Biotechnol.; doi:10.1038/nbt.2884; corrected online 31 March 2014}

In the version of this article initially published online, in the legend for Figure 1d, the scale bars are $100 \mu \mathrm{m}$ and $20 \mu \mathrm{m}$, not "mm." The error has been corrected for the print, PDF and HTML versions of this article. 